Louisiana State University

LSU Digital Commons

Faculty Publications

Department of Oceanography \& Coastal

Sciences

$12-1989$

\title{
Accretion and Canal Impacts in a Rapidly Subsiding Wetland II. Feldspar Marker Horizon Technique
}

Donald R. Cahoon

R. Eugene Turner

euturne@lsu.edu

Follow this and additional works at: https://digitalcommons.Isu.edu/oceanography_coastal_pubs

\section{Recommended Citation}

Cahoon, D. R., \& Turner, R. (1989). Accretion and Canal Impacts in a Rapidly Subsiding Wetland II. Feldspar Marker Horizon Technique. Estuaries, 12 (4), 260-268. Retrieved from https://digitalcommons.Isu.edu/ oceanography_coastal_pubs/159

This Article is brought to you for free and open access by the Department of Oceanography \& Coastal Sciences at LSU Digital Commons. It has been accepted for inclusion in Faculty Publications by an authorized administrator of LSU Digital Commons. For more information, please contact ir@lsu.edu. 


\title{
Accretion and Canal Impacts in a
}

\section{Rapidly Subsiding Wetland}

\section{Feldspar Marker Horizon Technique}

\author{
Donald R. CAHOON ${ }^{1}$ \\ R. EUGENE TURNER \\ Coastal Ecology Institute \\ Center for Wetland Resources \\ Louisiana State University \\ Baton Rouge, Louisiana 70803
}

\begin{abstract}
Recent (6-12 month) marsh sediment accretion and accumulation rates were measured with feldspar marker horizons in the vicinity of natural waterways and man-made canals with spoil banks in the rapidly subsiding environment of coastal Louisiana. Annual accretion rates in a Spartina alterniftora salt marsh in the Mississippi deltaic plain averaged $6 \mathrm{~mm}$ in marsh adjacent to canals compared to $10 \mathrm{~mm}$ in marsh adjacent to natural waterways. The rates, however, were not statistically significantly different. The average rate of sediment accretion in the same salt marsh region for a transect perpendicular to a canal $\left(13 \mathrm{~mm} \mathrm{yr}^{-1}\right)$ was significantly greater than the rate measured for a transect perpendicular to a natural waterway $\left(7 \mathrm{~mm}^{-1} \mathrm{r}^{-1}\right)$. Measurements of soil bulk density and organic matter content from the two transects were also different. This spatial variability in accretion rates is probably related to (1) spoil bank influences on local hydrology; and (2) a locally high rate of sediment input from lateral erosion associated with pond enlargement. In a brackish Spartina patens marsh on Louisiana's Chenier plain, vertical accretion rates were the same along natural and canal waterways (3-4 $\left.\mathrm{mm} \mathrm{yr}^{-1}\right)$ in a hydrologically restricted marsh region. However, the accretion rates for both waterways were significantly lower than the rates along a nonhydrologically restricted natural waterway nearby $\left(11 \mathrm{~mm} \mathrm{yr}^{-1}\right)$. The vertical accretion of matter displayed semi-annual differences in the brackish marsh environment.
\end{abstract}

\section{Introduction}

The long-term growth, stability, or decay of geologically subsiding coastal wetlands can be very responsive to climatic, geologic, hydrologic, and biologic forces of both natural and man-made origin (Ranwell 1972; Daiber 1986). Sediment sources and distributions may change with local or national land use changes (e.g., Kesel 1988), the hydrological regime may be altered by natural and manmade levees (e.g., Swenson and Turner 1987), and plant communities discreetly adapt to slight variations in climate, soil chemistry, or management (e.g., Barbour 1978; Eilers 1980; Mendelssohn et al. 1981; Zedler 1983). The dynamic and interactive nature of these forces at work is conspicuously present in Louisiana, where both natural and man-made processes were important factors leading to wetland losses of $0.86 \% \mathrm{yr}^{-1}$ from 1955 to 1978 (Craig et al. 1979; Scaife et al. 1983; Turner and Cahoon 1987; Walker et al. 1987; Wells and Coleman 1987).

It is important to quantify sedimentation rates

\footnotetext{
' Present address: Louisiana Geological Survey, P.O. Box G, University Station, Baton Rouge, Loujsiana 70893.
}

to understand these changes because, in part, sedimentary processes are (1) responsive to changes in hydrologic and biologic processes, and (2) the rates of sediment accretion affect the ability of plants to adapt to the direct and indirect effect of relative and absolute variations in water level (Stevenson et al. 1986). Marsh sedimentation rates tend to be highest where plant density is greatest and marsh surface elevation is highest (e.g., Ranwell 1964). Because marsh water level may be influenced by dredge and fill activities (Swenson and Turner 1987), sedimentation rates and plant biomass may change to the detriment of the health of the marsh, but not until several years later. Here we report the results of a study of natural and manmade factors on short-term ( $\leq 1 \mathrm{yr})$ sediment accretion processes in coastal Louisiana marshes. It is part of a series of three papers (with DeLaune et al. 1989 and Knaus and Van Gent 1989) which the reader is advised to consult for further details about project rationale, site description, and other relevant aspects of sedimentary processes in these marshes.

Recent sedimentation rates can be estimated by recovering recent marker horizons such as feldspar or brick dust (Stearns and MacCreary 1957; De- 
TABLE 1. Mineral sediment and organic matter accumulation behind streamside levees (Natural), and continuous (Canal-c) and discontinuous (Canal-d) canal spoil levees in a Lafourche Parish salt marsh (means $\pm 1 \mathrm{SF}$, $\mathrm{n}=$ number of waterways with the total number of cores in parentheses). The vertical accretion, bulk density, and mineral/organic matter content measurements are based on 12 -month cores.

\begin{tabular}{|c|c|c|c|c|c|c|}
\hline \multirow[b]{2}{*}{ Waterway } & \multirow[b]{2}{*}{$n$} & \multirow{2}{*}{$\begin{array}{l}\text { Verticai } \\
\text { Accretion } \\
\text { cm } y^{-1}\end{array}$} & \multirow[b]{2}{*}{$\begin{array}{l}\text { Bulk Density } \\
\qquad \mathrm{cm}^{-3}\end{array}$} & \multirow[b]{2}{*}{$\% \min / \%$ org } & \multicolumn{2}{|c|}{ Accumulation } \\
\hline & & & & & $\begin{array}{c}\text { Mineral } \\
\mathrm{g} \mathrm{cm}^{-2} \mathrm{yr}^{-1}\end{array}$ & $\underset{8 \mathrm{~cm}^{-2} \mathrm{yr}^{-1}}{\text { Organic }}$ \\
\hline Canal-c & $3(7)$ & $0.66 \pm 0.25^{2}$ & $0.14 \pm 0.008^{2}$ & $70 / 30 \pm 5^{2}$ & $0.06 \pm 0.02^{\alpha}$ & $0.03 \pm 0.01^{2}$ \\
\hline Canal-d & $3(4)$ & $0.60 \pm 0.12^{2}$ & $0.10 \pm 0.007^{\mathrm{b}}$ & $64 / 36 \pm 3^{n}$ & $0.04 \pm 0.01^{2}$ & $0.02 \pm 0.01^{2}$ \\
\hline Natural & $4(9)$ & $0.99 \pm 0.20^{2}$ & $0.18 \pm 0.038^{=}$ & $74 / 26 \pm 3^{a}$ & $0.13 \pm 0.04^{2}$ & $0.05 \pm 0.01^{2}$ \\
\hline
\end{tabular}

" Means within a column followed by different letters are significantly different at the $5 \%$ level.

Laune et al. 1983; Baumann et al. 1984). We used the feldspar marker method in the field sites described in DeLaune et al. (1989). The feldspar methodology has several advantages compared to ${ }^{187} \mathrm{Cs}$ and ${ }^{210} \mathrm{~Pb}$ isotope marker techniques: $(1)$ it is much less expensive because it requires less complex equipment for collecting and processing samples; (2) sampling success is known at collection time because the marker is readily visible in the field; (3) core collection and processing are relatively simple and fast; and (4) it provides an estimate of recent $(\leq 1 \mathrm{yr})$ accretion events. By using both recent $(\leq 1 \mathrm{yr})$ and long-term (25 and 80-100 yr) sediment dating techniques simultaneously, a comparison can be made of historical and modern sedimentation patterns as well as testing for the influence of natural and man-made impacts.

The objectives of this study were to (1) measure recent marsh accretion, mineral sediment deposition, and organic matter accumulation rates in natural marshes and marshes altered by canals and their levees; (2) compare the influence of natural and man-made (i.e., canals) waterways on recent sedimentation processes; and (3) collect the data in a way that would allow comparison with recent and long-term sedimentation events in the same marsh area reported by DeLaune et al. (1989) and Knaus and Van Gent (1989).

\section{Methods and Experimental Design}

Feldspar marker horizon plots were established along bayou (natural, N) and canal (man-made, C) waterways in the marshes described in DeLaune et al. (1989, Figs. 2, 3, and 5). Eighty-eight plots were established in June and July 1986 in saline marshes in Lafourche Parish (L) and 24 plots in November 1986 and January 1987 in brackish marshes in Cameron Parish (C). No plots were established in the Terrebonne Parish marshes because of the unstable nature of the floating vegetative substrate. Field site designations are the same as those used in DeLaune et al. (1989) and are presented in Tables 1 and 2. An additional comparison was made in the brackish marshes of Cameron Parish. Results from sites along natural and canal waterways in a hydrologically restricted marsh were compared to data from a nearby nonhydrologically restricted bayou.

Accretion was measured behind the natural or spoil levees bordering waterways in Lafourche Parish at sites $50 \mathrm{~m}$ inland and along a $50-\mathrm{m}$ transect perpendicular to the waterways to analyze how accretion rates varied with distance from the waterways into the adjacent marsh. Marker horizons were laid down in $50 \times 50-\mathrm{cm}$ plots at all sites from small elevated wooden platforms $(3 \mathrm{~m} \times 1 \mathrm{~m})$ constructed parallel to the waterway at each site to facilitate finding the marker plots and to minimize disturbance of the marsh surface. Four marker plots were established at all nontransect sites: streamside (s), nonstreamside (ns), off the end of the platform (e), and one away from the platform (ab). This arrangement was designed to test for any possible platform effects on the distribution and accumulation of matter. Plot location at the platform was recorded within $5 \mathrm{~cm}$ and, in addition, two 3-mm diameter stakes were placed nearby. For the transect analysis, 50-m boardwalks were constructed perpendicular to a natural and man-made canal waterway in Lafourche Parish with sampling platforms spaced every $10 \mathrm{~m}$ from 0 to $50 \mathrm{~m}$ inclusive. Three feldspar marker horizon plots were established around each transect platform.

Our analysis of Cameron Parish samples is based only on a comparison of data from inland $(50 \mathrm{~m})$ sites. We cored the Lafourche plots after 6 months (June 1986-December 1986) and 12 months (June 1986-June 1987), and cored the Cameron plots after either 6 months (CBNr and CBC, January 1987-July 1987) or 8 months (CBN, November 1986-July 1987) and once again after 12 months (November 1986-November 1987 or January 1987-January 1988).

We used thin-walled aluminum beverage cans (6-cm diameter, with the top removed and an air vent in the remaining end) to take 8 - to $10-\mathrm{cm}$ long cores through the white feldspar marker horizon. We cored from previously unsampled areas of the 
TABLE 2. Comparisons of 6- and 12-month measurements of vertical accretion $(\mathrm{cm})$, organic matter content $(\%)$, and bulk density $\left(\mathrm{g} \mathrm{cm}^{-3}\right)$.

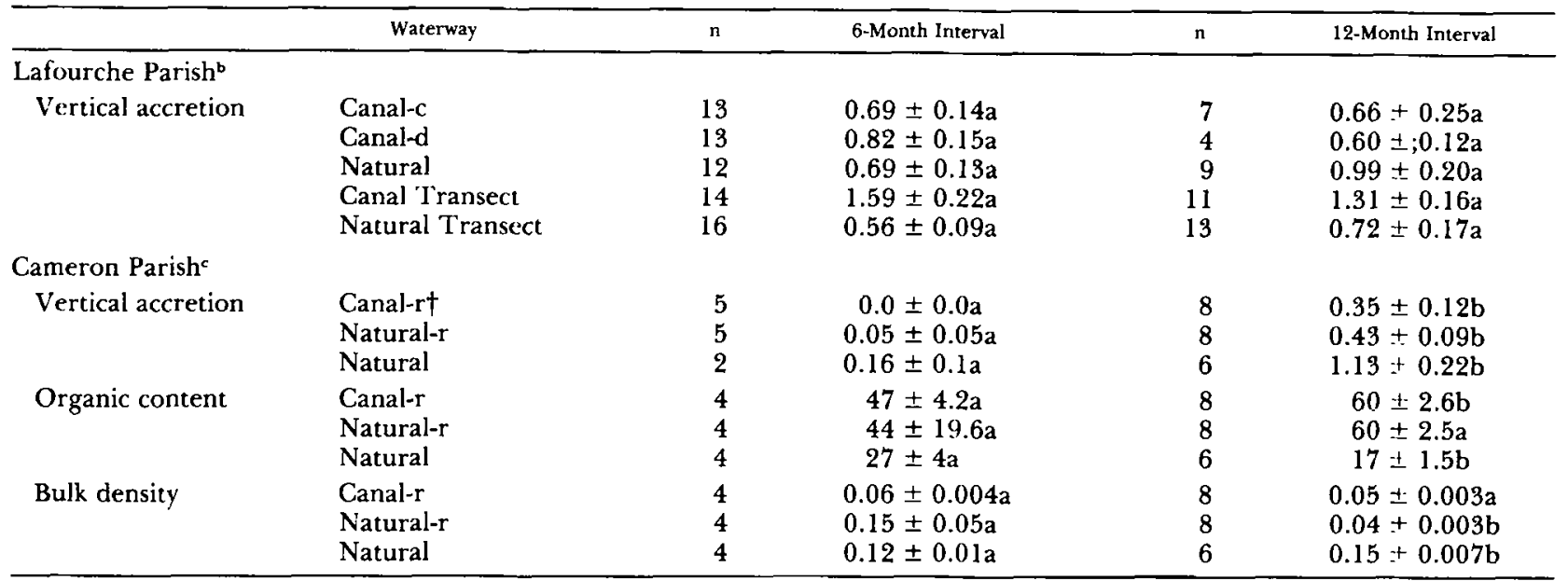

* Means within a waterway category followed by different letters are significantly different at the $5 \%$ level.

- Sampling intervals for Lafourche Parish samples were from summer-winter (6 months) and summer-summer (12 months).

- Sampling intervals for Cameron Parish samples were from winter-summer (6 months) and winter-winter (12 months).

† Samples were collected in two regions of the Cameron Parish marsh-a hydrologically restricted and a nonhydrologically restricted region. Natural and canal waterways in the hydrologically restricted region are designated Natural-r and Canal-r, respectively. Ihe natural waterway in the nonhydrologically restricted region is labelled Natural.

plot until the marker horizon was visible in the borehole. However, to limit disturbance in the plot, a core was retained after three or four attempts if no horizon was visible. The bottom of the core was sealed in the field with parafilm and stored in a vertical position. The sampled holes were filled with exogenous mud to prevent them from trapping sediments.

Cores were placed immediately in a freezer upon returning to the laboratory. The frozen cores were removed from the cans by slicing them in half along the vertical axis. The cut surface of the core was scraped smooth with a razor blade and the depth of sediment accumulated on top of the marker measured with a caliper at the center of the core and at $1 \mathrm{~cm}$ to either side of center. Hence, only the undisturbed center one-third of the core was measured. These values were averaged to obtain a final datum for each core.

The bulk density of the top $2 \mathrm{~cm}$ of marsh was measured from two or three cores at each platform after 12 months in Lafourche Parish (summer 1987) and after 6 and 12 months (summer 1987 and winter 1987-1988) in Cameron Parish. Bulk density cores were collected at the transect sites from the natural or artificial streamside levee and the six transect stations. We used a 60 -cc syringe with the tip cut off to sample sediment in areas immediately adjacent to the marker horizon plots. The percent mineral and organic matter were estimated for each bulk density core by ashing at $375^{\circ} \mathrm{C}$ for $16 \mathrm{~h}$ (Hesse 1971).
Data were analyzed with SAS ANOVA and NPAR IWAY (SAS 1985) statistical programs and tested at the $5 \%$ level. All larger data sets such as the 6-month data sets and average transect values were analyzed by ANOVA. Because of smaller sample sizes, all bulk density data (including percent organic and mineral data) from Cameron 6 -month and Lafourche 12-month data sets $(50 \mathrm{~m}$ and transect measurements) were analyzed by Wilcoxon (Rank Sums) nonparametric methods. The Cameron 12-month data were analyzed by ANOVA. All comparisons between 6- and 12-month core means were made by paired $t$-tests.

\section{Results and Discussion}

Intherpreting Feldspar Marker Cores

Success of the feldspar marker technique depends on recovering a clearly distinct artificial soil horizon in each core. A marker was recovered from most, but not all, plots. The success rate after 12 months was $100 \%$ for Cameron Parish brackish marshes $(95 \%$ after 6 months) and $58 \%$ for Lafourche Parish salt marshes ( $76 \%$ after 6 months). Other investigators have also "lost" feldspar markers placed in Louisiana wetlands (Baumann 1980; Miller 1983; DeLaune et al. 1983; Taylor 1988), but quantification of why recovery rates are less than $100 \%$ is heretofore absent from the literature. We can offer several reasons for the absence of markers in some cores. The feldspar marker should be distinctly evident as a white line in the recovered 
core for the method to be successful. A marker may not be present because (1) of bioturbation by birds, crabs and bivalves; (2) the marker was mixed with darker organic or inorganic materials to the point where it was not visible; (3) the marker was removed via tides or resuspension; or (4) the plot was missed during coring operations. Even if the marker is visible, it may be so disrupted that measurements of vertical accretion are inappropriate. Because we studied several marshes and cored many sites we can attribute some of the failures amongst the possibilities mentioned above.

The vast majority of unsuccessful cores in Lafourche Parish were uninterpretable because the marker horizon was not visible. Only $16 \%$ of the 6-month unsuccessful cores had a visible marker horizon that was too disrupted to measure accurately. The remaining $84 \%$ had no visible marker present. After 12 months, only 7\% of the unsuccessful cores were uninterpretable because of bioturbation of the marker feldspar, while $93 \%$ of the failed cores had no visible marker horizon present. We feel it is unlikely that we missed the plots because we took great care marking the plot location and collected cores from a plot until feldspar was found in the hole or four coring attempts had been made. Disappearance of the marker horizon could result from either lateral erosion from pond enlargement, in which case the marsh was replaced by open water, or from disruption (e.g., mixing or resuspension) of the marsh surface. Only one plot (in Lafourche Parish) out of 112 marker horizons established disappeared because of pond enlargement. Consequently, disruption of the marsh surface appears to be the most likely cause for failing to recover a marker horizon.

We did not include the cores with no visible marker in our calculation of the average accretion rate because it was not possible to determine if the absence of a marker resulted from either surface erosion or mixing processes. If disappearance of the marker horizon was primarily due to surface erosion, then the mean accretion rates we calculated are higher than the actual values. If markers were lost due to marker mixing or resuspension just after being laid down, then the calculated average accretion rates should not be overestimates. In the absence of a means to clearly separate the two possibilities, we followed the precedence of previous studies and included only cores with visible markers in our results.

\section{INFLUENCE of CANALS and SPOIL Banks ON Sediment Distribution \\ Salt Marsh Inland Comparisons}

The mean 12-month vertical accretion at the three inland marsh types in Lafourche Parish was
$0.99 \pm 0.20,0.66 \pm 0.25$, and $0.60 \pm 0.12 \mathrm{~cm}$ for the natural marshes, marshes with a continuous spoil bank, and marshes with a discontinuous spoil bank, respectively (Table 1). Although the mean vertical accretion rates in the natural marshes were about $50 \%$ higher than the mean accretion rates in marshes with spoil banks, the difference was not statistically significant. The mean net accretion between months 6 and 12 increased in the natural marshes, but decreased in marshes with spoil banks, although none of the differences were significant (Table 2).

The bulk density of the upper $2 \mathrm{~cm}$ of marsh soil ranged between 0.10 and $0.18 \mathrm{~g} \mathrm{~cm}^{-3}$ and was statistically lower in the marshes with discontinuous spoil banks than in the natural marshes or marshes with continuous spoil banks (Table 1). These values are similar to those reported by DeLaune et al. (1989) for the same site and within the range observed for Louisiana marshes (Gosselink et al. 1984). The higher mean percent organic matter and mineral accumulation in the natural marshes was not statistically different than for the other two treatments (Table 1). The presence of the sampling platform appears to have had no effect on vertical accretion rates, mineral accumulation, or organic matter content (Table 3).

Our 12-month vertical accretion measurements along the natural bayous were similar to those reported by Baumann et al. (1984) for the same marsh region and exhibited a similar seasonal pattern (i.e., winter flood waters were highly turbid and summer flood waters very clear). However, our 6-month measurements (summer-winter) were approximately twice those reported by Baumann et al. (1984), who reported regular increments in accretion of approximately $3-4 \mathrm{~mm}$ every 6 months from 1975 to 1979 , and were equal to our 12 month measurements (Table 2). Consequently, most accretion that we measured occurred during the summer-winter interval.

Caution should be exercised when interpreting the statistical analysis of mean accretion rates amongst the three treatments. Although treatment effects for most variables were not significantly different, the natural marshes had consistently higher values for vertical accretion $(p=0.54)$, bulk density $(p=0.03)$, mineral content $(p=0.14)$, and mineral accumulation $(p=0.18)$. The combination of reduced (i.e., small) sample size and high sample variability limited the statistical power of our test (i.e., the ability of the test to detect, as statistically significant, differences as great as 1.7 fold in vertical accretion and $>3$ fold in mineral accumulation). Therefore, we reserve judgement on any statistical analysis with a probability of $p \leq 0.20$ because the magnitude of differences displayed in this analysis 
TABLE 3. Vertical accretion rates (cm) for the replicate plot locations around the sampling platforms."

\begin{tabular}{|c|c|c|c|c|c|}
\hline & Waterway & $\mathrm{s}$ & E & NS & $A B$ \\
\hline Lafourche $50 \mathrm{~m}$ plots & $\begin{array}{l}\text { All } 6 \mathrm{mo} \\
\text { All } 12 \mathrm{mo}\end{array}$ & $\begin{array}{l}0.68 \pm 0.13 \\
0.72 \pm 0.24\end{array}$ & $\begin{array}{l}0.67 \pm 0.24 \\
1.03 \pm 0.39\end{array}$ & $\begin{array}{l}0.69 \pm 0.11 \\
0.88 \pm 0.28\end{array}$ & $\begin{array}{l}0.79 \pm 0.17 \\
0.66 \pm 0.22\end{array}$ \\
\hline Lafourche transect plots & $\begin{array}{c}\text { Canal-d } \\
6 \mathrm{mo} \\
12 \mathrm{mo} \\
\text { Natural } \\
6 \mathrm{mo} \\
12 \mathrm{mo}\end{array}$ & $\begin{array}{l}1.58 \pm 0.12 \\
1.00 \pm 0.3 \\
0.62 \pm 0.12 \\
0.49 \pm 0.14\end{array}$ & $\begin{array}{l}1.29 \pm 0.38 \\
1.47 \pm 0.17 \\
0.58 \pm 0.12 \\
1.04 \pm 0.38\end{array}$ & $\begin{array}{l}1.88 \pm 0.51 \\
1.50 \pm 0.26 \\
0.30 \pm 0.02 \\
0.62 \pm 0.29\end{array}$ & $\begin{array}{l}\text { NA } \\
\text { NA } \\
\text { NA } \\
\text { NA }\end{array}$ \\
\hline Cameron $50 \mathrm{~m}$ plots & $\begin{array}{l}\text { All } 6 \mathrm{mo} \\
\text { All } 12 \mathrm{mo}\end{array}$ & $\begin{array}{l}0.00 \pm 0.00 \\
0.54 \pm 0.19\end{array}$ & $\begin{array}{l}0.13 \pm 0.13 \\
0.60 \pm 0.22\end{array}$ & $\begin{array}{l}0.12 \pm 0.09 \\
0.74 \pm 0.27\end{array}$ & $\begin{array}{l}0.00 \pm 0.00 \\
0.45 \pm 0.10\end{array}$ \\
\hline
\end{tabular}

- The sampling platforms were constructed parallel to the waterway. Plot $S$ is located on the streamside of the platform, $E$ off the end of the platform, NS on the nonstreamside of the platform, and AB in the marsh 5-10 m away from the platform.

(e.g., $0.09 \mathrm{~g} \mathrm{~cm}^{-2} \mathrm{yr}^{-1}$ of mineral accumulation, Table 1) could be of long-term importance to the biological system, if, indeed, they are real. Taylor (1988) found that vertical accretion was 1.5 times greater in marshes along natural waterways compared to marshes behind spoil banks in low salinity wetlands north of our field sites (Fig. 1). She found that the natural sites had a lower bulk density, higher water content, and significantly greater organic content than the hydrologically restricted sites. Neill and Turner (1984) also found greater accretion at a natural brackish marsh in Terrebonne Parish compared to a nearby marsh with a spoil bank. The results from our study and from Taylor (1988) and from Neill and Turner (1984) support (but do not prove) the conclusion that spoil banks may influence sediment distribution in marshes; the results of these three studies are not unequivocable nor do they support this conclusion to the same degree. Unlike the other two studies, we cannot document statistically that accretion behind spoil banks is lower than in natural marshes, even though the mean accretion rate was considerably higher in the natural marsh. Because the signal to noise ratio was high and the difference between mean accretion rates considerable, we also do not think it appropriate to conclude that accretion rates at the Lafourche salt marsh inland sites were not influenced by canals and their spoil banks. This rather nondefinitive conclusion may be addressed better if cores are taken again after 2-3 $y r$ and the accretion continues (as anticipated). However, these conditions will not be met if the marsh erodes to a pond because of lower sedimentation rates behind the spoil banks.

\section{Salt Marsh Streamside vs. Inland Comparison}

Unlike the results of the inland marsh analysis, the canal and natural waterways analyzed in the streamside vs. inland comparison exhibited significantly different accretion rates. The average measurements (i.e., averaged for the entire transect) of vertical accretion, bulk density, and organic matter content were all significantly higher at the canal compared with the bayou transect site. This corroborates the findings of the ${ }^{137} \mathrm{Cs}$ and ${ }^{210} \mathrm{~Pb}$ analysis performed at the same location by DeLaune et al. (1989). However, there was no significant difference in vertical accretion between replicate plots in the vicinity of the platforms (Table 3 ).

Although the transect means for the canal and bayou sites were significantly different, there was no significant difference between streamside and inland marsh sites along either waterway in vertical accretion and percent organic matter for both the 6- and 12-month cores (Table 4). This is contrary to the results of DeLaune et al. (1978) and Baumann et al. (1984) who demonstrated an "edge effect" for salt marshes in this region of Lafourche Parish. However, 6-month accretion rates immediately behind the spoil bank were significantly lower at the $10 \%$ level $(p=0.06)$ compared to all other distances. Also, bulk density at the canal site differed with distance at the $10 \%$ level $(p=0.07)$. The largest mean difference $\left(0.22 \mathrm{~g} \mathrm{~cm}^{-3}\right)$ occurred between the spoil bank site, and 0 and $30 \mathrm{~m}$ behind it. It is likely that spoil bank bulk density could be nearly double the values in the marsh because the spoil levee is constructed with soil removed from as deep as $2 \mathrm{~m}$ below the live root zone of marsh vegetation. Bulk density also did not differ with distance at the bayou site. Consequently, mineral and organic matter accumulation did not differ with distance for both the bayou and canal transects (Table 4) because vertical accretion and percent organic matter did not change significantly with distance.

The lack of a "streamside or edge effect," and the reason why the transect means were different 


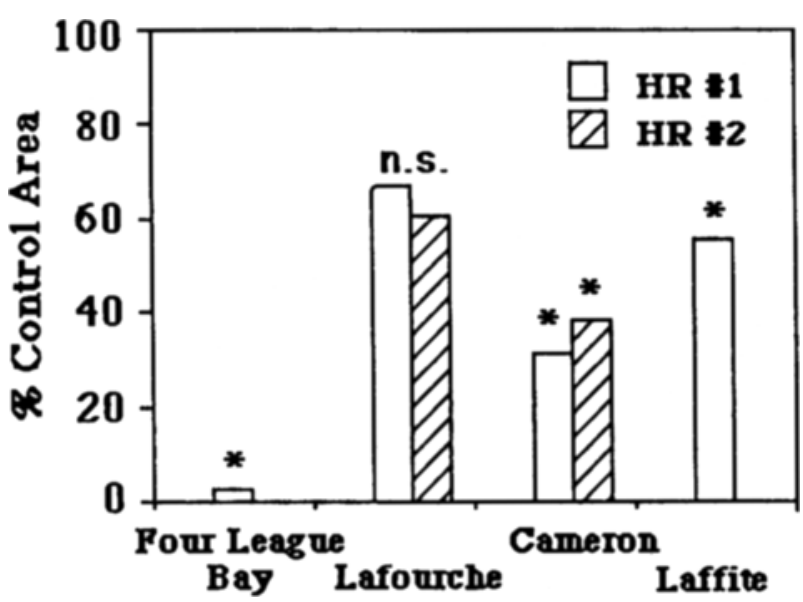

Fig. 1. Vertical accretion rates in hydrologically restricted areas (HR \#1 and HR \#2) compared to control sites nearby. The data are from Fourleague Bay (Neill and Turner 1984), Lafourche and Cameron parish (this study), and Lafitte (Taylor 1988). Data were normalized to the control site values (100\%). A "*" by the bar indicated a statistically significant difference between the hydrologically restricted site and the control site.

when the inland comparison was not, may be found by examining the local hydrologic conditions at the canal transect site. A spoil bank can be considered a barrier to typical overbank flooding and therefore direct sediment input from the canal to marshes behind them should be limited compared to natural waterways. Consequently, canals with spoil banks should not exhibit the edge effect (i.e., greater sediment accumulation at streamside locations than inland locations) typical of natural waterways.
Indeed, the pattern of sediment accumulation at the canal transect exhibited no edge effect; the lowest accumulation rates occurred at the $0-\mathrm{m}$ station immediately adjacent to the spoil bank (Table 4). This suggests that no overbank flooding occurred at the canal but occurred primarily along natural creeks away from the canal. In fact, no major storms strong enough to overtop the spoil banks occurred in this region during the study. The significantly greater amount of sediment accumulated at the canal transect could be explained, therefore, if the site was dominated by backwater flooding (flooding from around or behind the spoil bank) and the source of sediment was the breakup of inland marsh behind the spoil bank. This would also explain why there was no difference with distance behind the canal spoil bank in accretion rate.

Erosion at the marsh edge is a local source of material to be deposited at the study sites which may be distributed nonrandomly from the perspective of our sampling scheme. Marshes and tidal streams are not stationary over decades and there is, consequently, movement of materials into and out of a marsh. An additional source of accretionary materials occurs when there is a net loss of wetlands. A cursory review of aerial photographs within $1 \mathrm{~km}$ of the Lafourche Parish plots revealed many areas of marsh deterioration. If this material is redeposited locally it will add to the amount otherwise deposited. It may also mix with the marker horizon enough to disguise the marker.

Lateral erosion from pond enlargement has been

TABLE 4. Six- and 12-month vertical accretion rates, 12-month bulk density, and annual rates of mineral sediment and organic matter accumulation behind streamside levee (natural waterway) and discontinuous man-made canal spoil levec (canal-d) in a Lafourche Parish salt marsh (means \pm 1 SE; $n=$ number of successful cores).

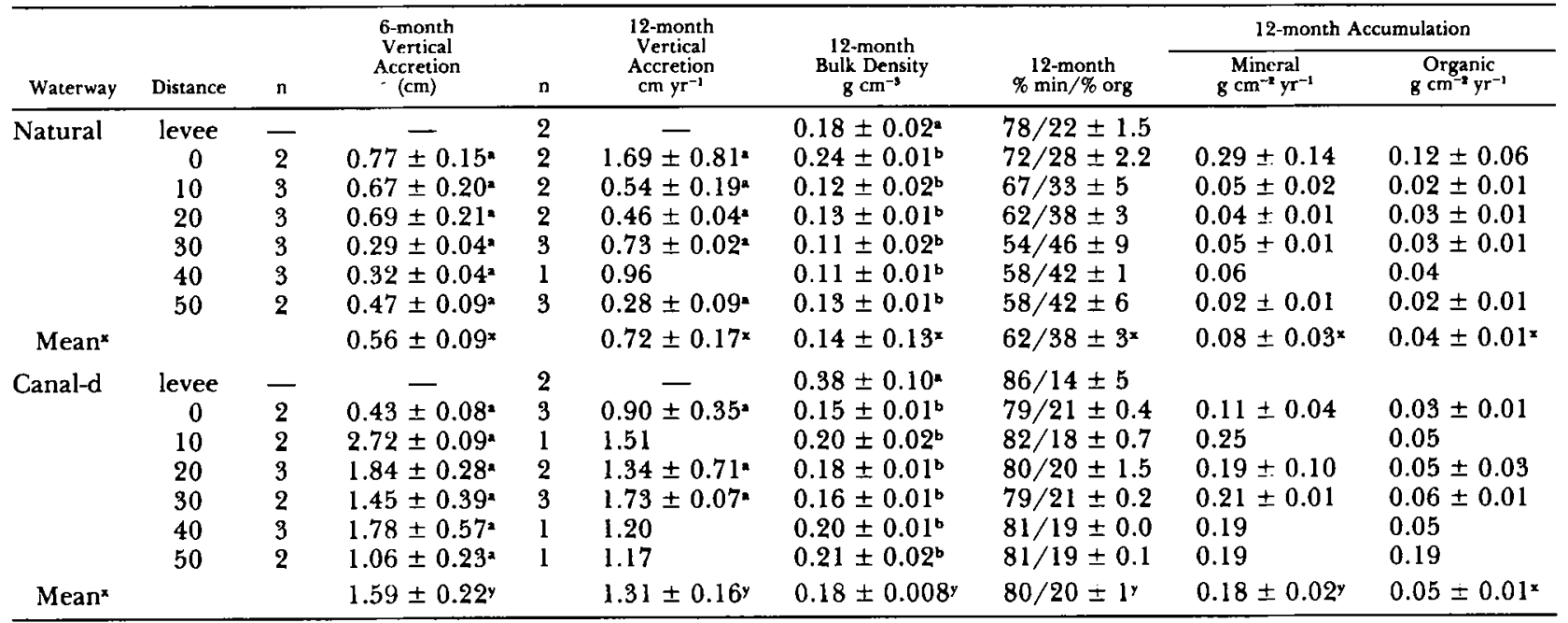

a Distance means within a column followed by different letters are significantly different at the $5 \%$ level.

$\times$ Transect means within a column followed by different letters are significantly different at the $5 \%$ level. 
TABLE 5. Mineral sediment and organic matter accumulation behind streamside levees (natural and artificial) in natural and hydrologically restricted brackish marsh in Cameron Parish (means \pm 1 SE, $n=$ number of platforms with the total number of cores in parentheses). The vertical accretion, bulk density and mineral/organic matter measurements are based on 12-month cores.

\begin{tabular}{|c|c|c|c|c|c|c|}
\hline \multirow[b]{2}{*}{ Waterway } & \multirow[b]{2}{*}{$n$} & \multirow[b]{2}{*}{$\begin{array}{c}\text { Vertical Accretion } \\
\mathrm{cm} \mathrm{yr}^{-1}\end{array}$} & \multirow[b]{2}{*}{$\begin{array}{l}\text { Bulk Density } \\
\mathrm{g} \mathrm{cm}^{-3}\end{array}$} & \multirow[b]{2}{*}{$\% \min / \%$ org } & \multicolumn{2}{|c|}{ Accumulation } \\
\hline & & & & & $\begin{array}{c}\text { Mineral } \\
\mathrm{g} \mathrm{cm}^{-2} \mathrm{yr}^{-1}\end{array}$ & $\begin{array}{c}\text { Organic } \\
\mathrm{g} \mathrm{cm}^{-2} \mathrm{yr}^{-1}\end{array}$ \\
\hline Natural & $2(6)$ & $1.13 \pm 0.22^{2}$ & $0.15 \pm 0.007^{\prime}$ & $83 / 17 \pm 1.5^{2}$ & $0.14 \pm 0.03^{2}$ & $0.03 \pm 0.05^{a}$ \\
\hline Canal-r & $2(8)$ & $0.35 \pm 0.12^{\mathrm{b}}$ & $0.05 \pm 0.003^{b}$ & $40 / 60 \pm 2.6^{b}$ & $0.007 \pm 0.02^{\mathrm{mb}}$ & $0.11 \pm 0.04^{2}$ \\
\hline Natural-r & $2(8)$ & $0.43 \pm 0.09^{b}$ & $0.04 \pm 0.003^{b}$ & $40 / 60 \pm 2.5^{b}$ & $0.006 \pm 0.01^{\mathrm{b}}$ & $0.09 \pm 0.02^{x}$ \\
\hline
\end{tabular}

- Means within a column followed by different letters are significantly different at the $5 \%$ level (Scheffe test).

suggested to produce an edge effect in sediment distribution (DeLaune et al. 1983). The fact that the one plot that eroded from pond enlargement had $21.9 \mathrm{~mm}$ of material accumulate above the marker horizon in just 6 months supports this contention. The marsh at the canal transect had more ponds (open water) along it than the natural transect. The canal sampling sites at 10, 20, 30, 40, and $50 \mathrm{~m}$ were adjacent to open water ponds, most of which were connected to one another and eventually to the adjoining lakes on either side of the transect (sec DeLaune et al. 1989, Fig. 3). All but one sampling site had a direct waterway connection to the larger waterbody. The only exception was the $0-\mathrm{m}$ site, which was immediately adjacent to the spoil bank levee, and which had the lowest accretion and accumulation rates. In addition, spoil banks have been shown to influence flooding patterns by prolonging periods of drought and inundation (Swenson and Turner 1987). The combined effect of these changes (i.e., altered hydrology and local sediment source) could explain, at least in part, not only why the canal site had higher sediment accumulation rates but also why there was a large variance in accretion rates within the study region for both the $50-\mathrm{m}$ and transect analyses.

\section{Brackish Marsh Inland Comparison}

Annual vertical accretion rates of recently deposited marsh sediments in the brackish marsh at Cameron Parish were 0.4-1.1 cm (Table 5), similar to that for the Lafourche Parish salt marsh (0.6$1.0 \mathrm{~cm}$, Table 1). Although vertical accretion rates increased significantly from 6 to 12 months (Table 2), annual (12 month) vertical accretion rates behind the hydrologically restricted waterways $(\mathrm{Ca}-$ nal-r and Natural-r) in the Cameron region were not significantly different from one another (Table 5 ). The percent soil organic matter increased from 6 to 12 months at the hydrologically restricted canal site (Table 2) while soil bulk density decreased significantly at the natural restricted site.

Most sediment at the Cameron Parish brackish marsh accumulated during the fall and early winter
(July-November and July-January) (Täble 2). Nine of the 12 successful cores collected in the brackish marsh at months 6 to 8 had no measurable sediment accumulation, while all but one core collected at month 12 had measurable sediment buildup. DeLaune et al. (1983), studying the same marsh region, did not report any seasonality in measured vertical accretion. It is not clear whether this difference among results is due to natural annual variation in basin water level and storm events, man-induced changes, or some other influence. However, the construction of a water control levee along Lake Calcasieu is notable because it occurred after the DeLaune et al. (1983) study and clearly restricts water flow (its purpose) into and out of the marshes we both sampled.

$$
\begin{gathered}
\text { Brackish Marsh-Influence of } \\
\text { Regional Hydrology }
\end{gathered}
$$

Marshes adjacent to natural and canal waterways in the hydrologically restricted portions of the Cameron Parish study region had significantly lower accretion rates than marshes adjacent to a natural waterway with close and direct hydrologic connection to Lake Calcasieu. The bulk density and organic matter content of the top $2 \mathrm{~cm}$ of marsh soil also were significantly lower at the hydrologically restricted waterways after 12 months (Table 5) compared to the nonrestricted region. The hydrologically restricted northern end of the Cameron Parish sampling region is characterized by shallow, silted-in water bodies. The closest direct hydrologic connection between the region and Lake Calcasieu is greater than $7 \mathrm{~km}$ away. The annual accretion rates estimated by the feldspar marker horizon method in this hydrologically restricted setting are only $41 \%$ to $90 \%$ of those estimated from 25-yr cores (DeLaune et al. 1989). Vertical accretion rates apparently have slowed in this marsh region during the past $25 \mathrm{yr}$, but canal spoil banks appear to have little additional influence on sediment distribution compared to natural streamside levees. We do not know if this change has been caused by the new levee or some previous habitat alteration (e.g., the Calcasieu Ship Channel) be- 
cause the area began silting-in before the construction of the flood-control levee (C. Lemaire, Sweet Lake Land and Oil Company, personal communication). Nevertheless, this hydrologically restricted region has only one-third the vertical accretion rate of the natural sites in Sabine National Wildlife Refuge and the new levee probably contributes to this decline in sedimentation. Consequently, this area likely depends to a greater extent on the accumulation of organic matter and on episodic sediment inputs from major storms to maintain its elevation.

\section{Conclusions}

The influence of canals and their associated spoil banks on recent accretion phenomena varied with the environmental setting. Accretion rates were lower, but not statistically lower, in natural marshes compared to marshes with a spoil bank in a salt marsh; the brackish Cameron marshes had statistically higher accretion rates in natural marshes compared to marshes behind a large man-made levee. Whether a spoil bank is continuous or discontinuous appears to be relatively unimportant in the marshes we examined. There was no effect of distance to waterway on sedimentation patterns for either canal or natural sites in a salt marsh, but the average vertical accretion rate, soil bulk density, and organic matter content for the canal transect were significantly greater than the transect in the natural marsh. We hypothesize that this result is related to locally high rates of lateral erosion of ponds at that site.

Accretion rates varied throughout the year and among sites. In Lafourche Parish, the rates from June to December did not differ from the June to June rates, but field observations showed that essentially all deposition in the saline marshes of southern Lafourche Parish was associated with the passage of winter cold fronts (also discussed by Baumann et al. 1984). However, most accumulation occurred in the late summer to fall in a hydrologically restricted brackish marsh in Cameron Parish, which is different from the results described by Delaune et al. (1983). They found no seasonal trends in the same marshes before a major floodcontrol levee was built.

\section{ACKNOWLEDGMENTS}

We thank R. Delaune, R. Knaus, H. Roberts, D. Van Gent, and $\mathrm{J}$. Whitcomb for critically reviewing the manuscript and $\mathrm{J}$. Donley for editing. G. Peterson and R. Baumann provided technical advice on marking and coring procedures. R. Knaus, D. Van Gent, W. DeLaune, R. Winston, J. Lee, M. Koch, W. Hoekstra, S. Harrell, G. King, S. Brown, K. Edds, J. Cowan, S. Hamilton, E. Swenson, R. Kaswadjii, and K. Gele provided capable assistance in the field. $R$. Winston and $K$. Gele assisted in the laboratory and Drs. J. Geaghan and J. Cowan provided valuable advice on statistics. The field work for this study would not have been possible without the generosity and cooperation of the following landowners: Continental Land and Fur, Inc.; USFWS, Sabine National Wildlife Refuge; Miami Corporation; and Sweet Lake Land and Oil Company. This research was funded by the Minerals Management Service of the U.S. Department of the Interior under MMS contract number 14-12-0001-30252.

\section{Literature Cited}

BARBOUR, M. G. 1978. The effects of competition and salinity on the growth of a salt marsh plant species. Oecologia 37:9399.

BaUMANN, R. H. 1980. Mechanisms of maintaining marsh elevation in a subsiding environment. M.S. 'Thesis, Louisiana State Univ., Baton Rouge, Louisiana. 92 p.

Baumann, R. H., J. W. Day, JR., and C. A. Miller. 1984. Mississippi deltaic wetland survival: Sedimentation versus coastal submergence. Science 224:1093-1095.

Craig, N. J., R. E. 'Turner, and J. W. Day. 1979. Land loss in coastal Louisiana (U.S.A.). Environ. Management 3:133144.

Daiber, F. C. 1986. Conservation of Tidal Marshes. Van Nostrand Reinhold Co., Inc., New York. 341 p.

Del.aune, R. D., W. H. Patrick, Jr., and R. J. Buresh. 1978. Sedimentation rates determined by ${ }^{137} \mathrm{Cs}$ dating in a rapidly accreting salt marsh. Nature 275:532-533.

DeL.aune, R. D., R. H. Baumann, and J. G. Gosselink. 1983. Relationships among vertical accretion, coastal submergence, and erosion in a Louisiana Gulf coast marsh. J. Sed. Petrol. 53:147-157.

Delaune, R. D., J. H. Whitcomb, W. H. Patrick, JR., J. H. Pardue, and S. R. Pezeshk1. 1989. Accretion and canal impacts in a rapidly subsiding wetland. $1 .{ }^{137} \mathrm{Cs}$ and ${ }^{210} \mathrm{~Pb}$ techniques. Estuaries 12:247-259.

EILERS, H. P. 1980. Fcology of a coastal salt marsh after longterm absence of tidal fluctuations. Bull. South. Calif. Acad. Sci. 79:55-64.

Gosselink, J. G., R. Hatton, and C. S. Hopkinson. 1984. Relationship of organic carbon and mineral content to bulk density in Louisiana soils. Soil Sci. 137:177-180.

Hesse, P. R. 1971. A Textbook of Soil Chemical Analysis. John Murray Publishers, Ltd., London. 520 p.

KFsel, R. H. 1988. The decline in the suspended load of the lower Mississippi River and its influence on adjacent wetlands. Environ. Geol. Water Sci. 11:271-281.

Knaus, R. M., AND D. VAN GeN'T. 1989. Accretion and canal impacts in a rapidly subsiding wetland III. A new soil horizon marker method for measuring recent accretion. Estuaries 12: 269-283.

Mendelssohn, I. A., K. L. McKee, and W. H. Patrick, Jr. 1981. Oxygen deficiency in Spartina alterniflora roots: Metabolic adaptation to anoxia. Science 214:439-441.

Mit.LER, C. A. 1983. Sediment and nutrient inputs to the marshes surrounding Fourleague Bay, Louisiana. M.S. 'Thesis, Louisiana State Univ., Baton Rouge, Louisiana. 68 p.

Neill, C., ANd R. E. TURner. 1984. Sedimentation rates and soil properties near backfilled canals and backfilled canal spoil banks. Chapter 6. In An Evaluation of the Backfilling of Canals as a Means of Mitigating the Environmental Impacts of Canals in South Louisiana. Final Report to the Coastal Management Division, Department of Natural Resources, Baton Rouge, Louisiana.

RANWELL, D. S. 1964. Spartina salt marshes in southern England. II. Rate and seasonal pattern of sediment accretion. J. Ecol. 52:79-94.

RANWELL, D. S. 1972. Ecology of Salt Marshes and Sand Dunes. John Wiley and Sons, Inc., New York. 258 p.

SAS INSTITUTE, INC. 1985. SAS User's Guide: Statistics, Ver- 
sion 5 edition. SAS Institute Inc., Cary, North Carolina. $956 \mathrm{p}$.

Scaife, W. B., R. E. Turner, and R. Costanza. 1983. Recent land loss and canal impacts in coastal Louisiana. Environ. Management 7:433-442.

Stearns, L. A., and D. MacCreary. 1957. The case of the vanishing brick dust. Mosquito News 17:303-304.

Stevenson, J. C., L. G. WARd, and M. S. Kearney. 1986. Vertical accretion in marshes with varying rates of sea level rise, p. 241-259. In D. A. Wolfe (ed.), Estuarine Variability. Academic Press, Inc., Orlando, Florida.

Swenson, E. M., ANd R. E. Turner. 1987. Spoil banks: Effects on a coastal marsh water-level regime. Estuarine Coastal Shelf Sci. 24:599-609.

TAYLOR, N. C. 1988. Ecological characterization of Jean Lafitte National Historical Park, I ouisiana: Basis for a management plan. M.S. Thesis. Louisiana State Univ., Baton Rouge, Louisiana. $160 \mathrm{p}$.
Turner, R. E., and D. R. Cahoon. (eds.). 1987. Causes of wetland loss in the coastal central Gulf of Mexico. Volume II: Technical Narrative. Final report submitted to Minerals Management Service, New Orleans, Louisiana. OCS Study/ MMS 87-0120. 400 p.

Walker, H. J., J. M. Coleman, H. H. Roberts, and R. S. Tye. 1987. Wetland loss in Louisiana. Geogr. Ann. 69(A):189-200. Wells, J. T., AND J. M. Coleman. 1987. Wetland loss and the subdelta life cycle. Estuarine Coastal Shelf Sci. 25:111-125.

ZEDLER, J. B. 1983. Freshwater impacts in normally hypersaline marshes. Estuaries 6:346-355.

Received for consideration, May 25, 1988 Accepted for publication, April 16, 1989 